\title{
Factor XI Deficiency
}

National Cancer Institute

\section{Source}

National Cancer Institute. Factor XI Deficiency. NCI Thesaurus. Code C131739.

A coagulation disorder characterized by the partial or complete absence of factor XI activity in the blood. 